\title{
Family-Based Care for Children with Disabilities in South Tangerang City, Indonesia
}

\author{
Lisma Dyawati Fuaida \\ Social Welfare Study Program \\ Syarif Hidayatullah State Islamic University \\ Jakarta, Indonesia \\ lisma.fuaida@uinjkt.ac.id
}

\author{
Ellies Sukmawati \\ Social Welfare Study Program \\ Syarif Hidayatullah State Islamic University \\ Jakarta, Indonesia \\ ellies.sukmawati@uinjkt.ac.id
}

\begin{abstract}
In Indonesia there is a paradigm shift from institution-based care to family-based care. The paradigm shift led to a new regulation that requires all institution-based systems to strengthen and develop an alternative family-based care system. There are not many institution-based care systems for supporting family-based care programs for disabled children. This article explores family support services for families with disabled children in South Tangerang, Indonesia. The study describes challenges and issues, and focuses on efforts of Sayap Ibu Foundation to strengthen the families' capabilities to survive and prepare better futures for their disabled children. The research used a qualitative-descriptive approach by interviewing four staff, six families with children with disabilities, and six community members. The study finds that family-support services have not been able to deliver services and provide the rights appropriate for the significant numbers of children with disabilities. The limited services were caused by scarcity of human resources even though there are volunteers to help support families with disabled children. The result of the study concludes that there is a critical need for communitybased care programs to strengthen support for the families with disabled children to make them feel socially included in society.
\end{abstract}

Keywords: Family Care; Family Support; Family-Based Care; Children; Multiple Disabilities; Government Regulation; Social Work.

\section{INTRODUCTION}

The emergence of the National Standards of Care for Social Welfare Institution in 2011 marked the beginning of a paradigm shift from institutional-based care to alternative care and strengthened family-based care in Indonesia. It was drafted as a response to the recommendation of the United Nation's Committee on the Rights of the Child in their feedback to the Indonesian Government's 2004 report on the implementation of the Convention on the Rights of the Child [1, p. 23].

The drafting of the National Standards of Care for Social Welfare Institution was based on two important research studies conducted by Save the Children and the Indonesian Ministry of Social Affairs with support from UNICEF. The two studies have allowed the elaboration of some key points related to the role of institution in supporting family-based care and carrying out alternative care, and the situtation where children need institutionbased care. The name of Child Care Center (Panti Asuhan Sosial Anak) is changed to Child Social Welfare Institution (Lembaga Kesejahteraan Sosial Anak) in order to put the role and function of social welfare institutions in child care appropriately.[2, pp. 3-6]

In addition, some policies on care have been issued to strengthen family-based care for children with disabilities, e.g. The 2010 Operational Guidelines for Child Welfare and the 2015 Models of Family-and-SocietyBased Protection and Social Rehabilitation for Children with Disabilities issued by the Ministry of Social Affairs.

While institutions providing care for children with disabilities are among Child Social Welfare Institutions, there are not many institution-based care systems that could support family-based care program for children with disabilities. In South Tangerang, there is only one institution that provides care for neglected children with multiple disabilities namely Sayap Ibu Foundation. The institution itself provides family-based care for children with disabilities from Jakarta, Bogor, Depok, Tangerang, and Bekasi. This indicates that such an institution is quite rare and, on the other hand, the demand for that care is quite high.

There are some researchs on family-based care for children with disabilities in Indonesia. Martin \& Sudrajat [3] have successfully promoted the mainstreaming of family-based child care system in Indonesia. Therefore they have not yet deal with disabled child care even though their study has encouraged the government to draft a policy framework to sustain family support services for children in families facing certain challenges.

Some studies on family-based care for children with disabilities take a different focus. Rosenbaum et al.[4, pp. 1-2] provide a brief history of family-centered services, review research-based evidence that support familycentered services, and generate areas for further research. This study encourages care providers to shift to familycentered services and promote the possibility of that framework to be used in education and research.

Another study on the child behaviour in a familybased case setting was conducted by James et al. who compare it with teenagers in group-care setting during several episodes. While the result shows no significant difference in behavior between the two groups[1, p. 153], James has paid attention to the application of family-based care setting.

On the other hand, Malekpour et al.[5] argues that family-child based intervention can help child control his/her behavior, and at the same time help parents understand how they should behave toward their children. Thus, the two elements help cure ADHD symptoms among the children. 
Another study by Sindi [6] illusrates the changing process from institutional child substitute care to familybased care that have occured since the independence of Estonia in 1991.

The studies previously mentioned have not yet dealt with the implementation of family-based care for children with disabilities quite specifically. However, the framework made by Rosenbaum et al. is good enough to explore the care services provided for families with disabled children in South Tangerang. Therefore, using the framework, this study shows the challenges, issues, and focuses in the efforts to strengthen the capacity of families to survive and prepare for the better future for children with disabilities.

Rosenbaum's Framework of Family-Centered Service: Premises, Principles, and Elements

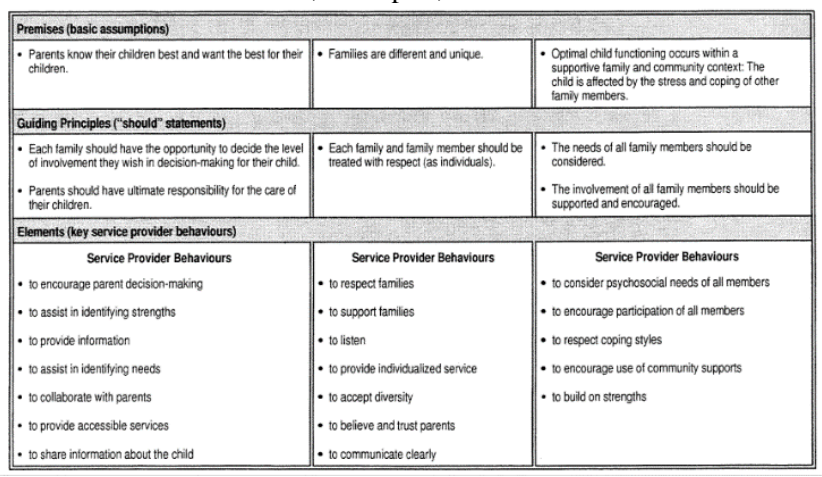

Rosenbaum et al. (1998, p. 6)

The first premise of the framework is that parents know their children best and want the best for their children. Therefore, each family should have the opportunity to decide the level of involvement they wish in decision-making for their child; and parents should have ultimate responsibility for the care of their children. Based on this premise, service providers must encourage parent decision-making, assist in identifying strengths, provide information, assist in identifying needs, collaborate with parents, provide accessible services, and share information about the child.

The second premise of the framework is that families are different and unique. Therefore, each family and family member should be treated with respect (as individuals). Based on this premise, service providers must respect families, support families, listen, provide individualized service, accept diversity, believe and trust parents, communicate clearly.

The third premise is that optimal child functioning occurs within a supportive family and community context. In other words, the child is affected by the stress and coping of other family members. Based on this assumption, the needs of all family members should be taken into account and the involvement of all family members should be supported and encouraged. Based on this premise, service providers must consider psychosocial needs of all members, encourage participation of all members, respect coping styles, encourage use of community supports, and build on strengths (Rosenbaum et al., 1998, p. 6).

Based on the framework, this study seeks to deal with how social workers have worked in families with disabled children to implement family-based care system in South Tangerang using the abovementioned three premises. In particular, this study deals with the problems, challenges, and needs of those social workers.

\section{METHODS}

This study uses descriptive-qualititative approach. Data were collected by interviewing 4 staff of Sayap Ibu Foundation, 6 families with children with disabilities, and 6 citizens/members of society living around the families over a period of 6 months. In addition, participant observation was also held in family development forum. The families were purposely selected in a way that they would reflect diversity along a variety of factors including type of disability, two or single parents families, and area of living[7].

In depth interview for each of the families were conducted once that lasting from 2 hours with open-ended questions. All parents were interviewed in their homes during visit. The data also collected through observation in family forum or family development session.

\section{RESULT AND DISCUSSION}

This study finds three major issues. First, challenges facing family with disabled child. The two main challenges facing family with disabled child are poverty and stress. For certain families, poverty is a classical problem even since a disabled child was born among them. The presence of the disabled child could make their economic burden heavier because the child needs special health care. Quite often children with disabilities need certain therapies suitable for the kind of disability they have. They also need special education or inclusive school, which is still difficult to find. Transporting a disabled child to a health center or a school is another problem because of the lack of money for transportation. All needs of children with disabilities mean additional uneasy spending for families with low incomes.

The presence of a child with a disability could also trigger stress due to the inability of the family to accept the situation. The denial of a father or mother for a child's disability may trigger stressful divorce and result in a child neglect. In some cases, fortunately, relatives grandmother, grandfather, aunt, etc. - take the role of providing care instead of the child's parent. Even though the relatives also still struggle with their own poverty, they try to help the child out of their compassion.

The inability of parents to communicate with disabled children also often trigger frustration. The lack of ability to treat a disabled child with special needs could make the situation even worse.

Second, challenges facing social workers in implementing family-based care system for disabled children. Social workers have their own challenges to implement family-based care as required by the Ministry of Social Affairs's Protection Modul. The social workers meant here are those working for an NGO in South Tangerang targeting 350 families with disabled children. The NGO have ten programs to provide family-based child care as follows: 1) counseling on early detection and early intervention for children with disabilities as a preventive action to decrease the number of children being born with disabilities, which is conducted in areas with little 
information; 2) free physiotherapy for children conducted twice a week according to the need of each child; 3 ) training of parenting skill to improve the ability of parents in taking care of children with disabilities; 4) family development session (FDS)/family forum that helps parents know well the rights of the disabled child and what to do to make the disabled child more self-sufficient. In this forum, a facilitator address certain topics for discussion, such as the rights of the disabled child, the stages of child growth, children's behavior, and child attachment; 5) outreaching, that is visiting the houses where children with disabilities live; 6) health care according to the stage of child growth, such as vaccination, fulfillment of balanced nutrition, and the monitoring of child development, specialist doctors service, and health insurance; 7) disability counseling, which gives parents an opportunity to consult their problems in taking care of children with disabilities; 8) training of productive business, urged by the fact that many children are left at home by their parents who work outside (as wash laborer, housemaid, etc.); it is expected by this program that parents could work at home while taking care of their children; 9) education for children with disabilities, a three times a week activity, which is made relevant to the age of the disabled child; 10) supplementary nutrition, which gives more nutrition to children, such as milk and supplements. In addition, diapers are also given to children not being toilet-trained yet. Some of these ten programs, there exist some challenges facing social workers, particularly when they have direct interaction with the families with disabled children.

In the program of family development session, social workers should have attentive listening skill, which could help them listen and understand the problem facing the family. Social workers could not expect that the family will focus on talking about the problems facing the child with a disability. When a dialogue starts, parents may talk about all problems the family has, from economic problems, uneasy relationship, divorce, etc. Social workers should respect the participants and not limit the time to talk for a participant even when they think that all participants should have their opportunity to talk in the rest of time. Social workers could not limit the discussion only on the problems facing children with disabilities, because any problem in a family is, either directly or indirectly, related to the child - in accordance with the third premise.

The second challenge is that the place where a family forum is conducted, is sometimes less suitable and less widespread so the forum could not involve all clients. Not all families could attend the place of disability service because of transportation cost. If the place is widespread enough, and the number of social workers is sufficient to do that, the involvement of the participants could be maximized. Limited facilities and a lack of social workers, compared to the high number of clients, are an impediment for an excellent service.

The third challenge is during the outreaching. Social workers are challenged to link a family with existing resources - either formal (a government program) or informal (from the community). There have been many Indonesian government assistance programs that target families with disabled children, like the Family Hope program by the Ministry of Social Affairs, which gives a certain amount of money to families with disabled children for education. There is also a non-cash assistance in the form of Social Welfare Card, which is equipped with ewallet so it can be integrated with social assistance from other ministries, provincial governments, and social facilities like public transport and educational facilities. In addition, there is also an "e-warong" (joint electronic store) administered by the disabled. In terms of health program, the central government, provincial/municipal governments, and the Ministry of Health have provided free services, including for the disabled. However, many families are not reached by those programs because of administrative and technical obstacles. In this regard, social workers should be skillful enough to advocate and maximize the existing resources to help families meet the rights of the disabled children. On the other hand, there is still a lack of informal resources from the community as well as a lack of awareness of children with disabilities nearby. Therefore, the challenge to provide an accessible service for the client as outlined by the first premise is quite high.

The next challenge is related to the considerable number of problems facing the families in terms of their internal relationship as caused by their unreadiness to serve the disabled child. The second premise in the framework, which requires individualized service, then becomes another great challenge. In counseling on disabilities, social workers should have a good skill of familycounseling. In fact, the three social workers working at the NGO are not senior social workers having supervised family counseling experience. Two of them are graduates of the bachelor of social welfare, and another social worker is a graduate of high school of social work, who cannot be considered as a professional social worker. They work with their own "style" without any case management and without any supervision from professional social workers.

Third, the need for work guidelines and trainings for social workers and care guidelines and trainings for families with disabled children. In line with the problems facing the families and the social workers, there should be an effort to bridge the gap between the limited number of social workers and the limited number of care units, that is by providing technical guidelines for social workers and families with disabled children, as well as organizing multiple trainings to improve the professionalism of the social workers.

For parents, a pocket book containing practical basic guidelines for caring, interacting and communicating with disabled children will balance their lack of knowledge that should they get in family parenting and family development session programs. Trainings on how deal with the behaviors of children with special needs and how to communicate with disabled childre are also greatly needed for parents.

For social workers, clear work guidelines are needed to better implement family-based care approach. The modul published by the Ministry of Social Affairs should be tranlated into more specific guidelines that are workable in the field. The guidelines would standardize the performance of social workers in providing assistance. 
Trainings are also needed for upgrading the professionalism of the social workers, particularly regarding the implementation of casework, groupwork and case management related to disabilities. So far, trainings conducted are dedicated for institution-based caregivers and mainly on therapies for children with disabilities. Relevant trainings could help social works promote case conference to address clients' newly found cases. Such a case conference is important for a more comprehensive treatment toward clients. This would help maximize the family-based care of children with disabilities.

The framework of Rosenbaum et al. could help discuss the three aforementioned issues found. In relation to the first premise, social workers have involved families in making the best decision regarding their disabled children through family forum, parenting skill training and counseling. Social workers also support the parents' full responsibility for caring their children. However, a challenge appear when the parents themselves do not take care of their children, do not accept them, and neglect them. Socil workers then try to reconnect the parents and the children, and raise their awareness of their responsibility.

With regard to the second premise, social workers meet a big challenge to implement individualized care. This is due to the gap in the ratio between social workers and clients.

Relevant to the third premise, which serves as the biggest challenge for social workers, social workers coud not pay adequate attention to the psychosocial needs of all family members. It is quite difficult to encourage the participation of all members particularly because each of them is busy with their own business. Involving the community is not easy as well because families with disabled children often do not want to show the presence of their disabled children due to their feeling of shame and their unwillingness to be burden for other people.

\section{CONCLUSIONS}

The study finds that family-support services have not been able to deliver services and provide the rights appropriate for the significant numbers of children with disabilities. The limited services were caused by scarcity of human resources even though there are volunteers to help support families with disabled children. The result of the study concludes that there is a critical need for communitybased care programs to strengthen support for the families with disabled children to make them feel socially included in society.

\section{REFERENCES}

[1] S. James, S. Roesch, and Z. Jin Jin, "Characteristics and Behavioral Outcomes for Youth in Group Care and Family-Based Care: A Propensity Score Matching Approach Using National Data," J. Emot. Behav. Disord., vol. 20, no. 3, pp. $144-156,2012$.

[2] "Standar Nasional Pengasuhan untuk Lembaga Kesejahteraan Sosial Anak." 2011.

[3] Fl. Martin and Sudrajat, "Someone that Matters: The Quality Care in Childcare Institutions in Indonesia," The Ministry of Social Affairs Republic of Indonesia, Save the Children in Indonesia UNICEF, Research, 2007.

[4] P. Rosenbaum, S. King, M. Law, G. King, and J. Evans, "FamilyCentred Service. Physical \& Occupational Therapy In Pediatrics," vol. 18, 1998.
[5] M. Malekpour, S. Aghababaei, and S. Hadi, "Effectiveness of Family, Child, and Family-Child Based Intervention on ADHD Symptoms of Students with Disabilities," Int. J. Spec. Educ., vol. 29, no. 2, pp. 1-6, 2004.

[6] I. Sindi, "Changing Discourses and Changing Institutional Child Substitute Care: New Terms and Processes Toward Family-Like and Family-Based Care," Child Care Pract., vol. 22, no. 1, pp. 5063, 2016.

[7] R. Bogdan and S. J. Taylor, Introduction to Qualitative Research Methods : A Phenomenological Approach to The Social Sciences. Jhon Wiley \& Sons, 1975. 